\title{
МИНЕРАЛЬНО-СЫРЬЕВАЯ БАЗА НЕМЕТАЛЛИЧЕСКИХ ПОЛЕЗНЫХ ИСКОПАЕМЫХ ЦЕНТРАЛЬНО-ЧЕРНОЗЕМНОГО РЕГИОНА И РАЦИОНАЛЬНОЕ ЕЁ ИСПОЛЬЗОВАНИЕ. СТАТЬЯ 1. СОСТОЯНИЕ МИНЕРАЛЬНО-СЫРЬЕВОЙ БАЗЫ НЕМЕТАЛЛОВ
}

\author{
А. Д. Савко, Д. А. Дмитриев, А. В. Крайнов, А. В. Милаш \\ Воронежский государственный университет \\ Поступила в редакцию 20 августа 2018 г.
}

\begin{abstract}
Аннотация: минерально-сырьевая база неметаллического сырья ЦЧР включает многие виды полезных ископаемых, наиболее востребованными из которых являются используемые в строительной индустрии. Это кристаллические породы докембрия, особенно граниты для получения высокопрочного щебня, а также мела и известняки для производства иемента, пески в качестве заполнителей для бетона и строительства автодорог. Имеются перспективы для производства остродефицитного балластного щебня из девонских базальтов. Нет ограничений по запасам кирпично-черепичного, кремнистого и керамзитового сырья. Месторождений керамических тугоплавких глин в регионе достаточно для обеспечения предприятий региона на долгие годы, тогда как запасы огнеупорных глин и перспективы их наращивания ограничены. В связи с разведкой первого месторождения вторичных каолинов и вмещзающих их квариевых песков в мамонской толще девона открываются значительные возможности для производства каолиновой и стекольной продукции в регионе. Значительные запасы формовочного, а также сорбционного сырья, представленного бентонитовыми глинами палеогена и неогена, иеолитсодержащими кремнистыми породами верхнего мела. Имеющиеся месторождения агрохимического сырья (желваковые фосфориты и глауконитсодержащие пески) с учетом обширных сельскохозяйственных угодий в регионе и недостатка минеральных удобрений могут быть вовлечены в разработку. Возможное освоение крупных медно-никелевых на юге Воронежской и титан-циркониевых месторождений в Тамбовской областях позволит нарастить запасы неметаллического сырья во вскрышных и вмещзающих породах. Это базальты вторичные каолины, мела, глауконитсодержашие пески, кирпичные суглинки, фосфориты, кремнистые породы. Разведанные месторождения расположень крайне неравномерно, их скопления тяготеют к крупным промышленным иентрам, для развития которых требовалось разнообразное минеральное сырьё.
\end{abstract}

Ключевые слова: строительное, керамическое, сорбиионное, стекольное, агрохимическое сырьё, пески, глины, известняки, доломиты, мела, силициты, глаукониты, фосфоритьл

\section{MINERAL-RAW MATERIAL BASE OF NON-METALLIC MINERAL RESOURCES OF CEN- TRAL BLACK EARTH REGION AND ITS RATIONAL USE. Article 1. SITUATION OF THE MINERAL-RAW MATERIAL BASE OF NON-METAL MINERAL}

\begin{abstract}
Central Black Earth region includes many types of minerals, the most popular of which are used in the construction industry. These are Precambrian crystalline rocks, especially granites for obtaining high-strength crushed stone, as well as chalk and limestone for cement production, sands as aggregates for concrete and road construction. There are prospects for the production of deficient ballast gravel from the Devonian basalts. There are no restrictions on the reserves of brick-tile, siliceous and expanded clay raw materials. Deposits of ceramic high-melting clay in the region are sufficient to provide enterprises of the region for many years, while reserves of refractory clays and prospects for their growth are limited. In connection with the exploration of the first deposit of secondary kaolins and the quartz sands in the Mamon thickness of the Devonian that encloses them, considerable opportunities exist for the production of kaolin and glass products in the region. Considerable reserves of the molding, as well as sorption raw materials represented by bentonite clays of the Paleogene and Neogene, zeolite-containing siliceous rocks of the Upper Cretaceous. The existing deposits of agronomic raw materials (nodular phosphorites and glauconite-
\end{abstract}


containing sands), taking into account the extensive agricultural land in the region and deficit of mineral fertilizers, can be involved in the development. The possible development of large copper-nickel deposits in the south of the Voronezh and titanium-zirconium deposits in the Tambov regions will increase significant reserves of non-metallic raw materials in overburden and enclosing rocks. These are basalts for secondary kaolins, chalk, glauconite-containing sands, brick loams, phosphorites, siliceous rocks. Explored deposits are situated extremely uneven, their clusters tend to large industrial centers, for the development of which required a variety of mineral raw materials.

Key words: construction, ceramic, sorption, glass, agronomical raw materials, sands, clays, limestones, dolomites, chalk, silicites, glauconites, phosphorites

Анализ современного состояния МСБ ЦЧР и конкурентоспособности имеющихся в районе месторождений полезных ископаемых позволяет назвать следующие основные их виды, определяющие экономику региона и являющиеся потенциалом её развития в будущем. Это железные и медно-никелевые руды, титан-циркониевые россыпи, цементное сырье, карбонатные породы, огнеупорные и тугоплавкие глины, строительные камни, пески, пресные и минеральные подземные воды. Неметаллические из них являются весьма важными для экономики не только ЦЧР, но в ряде случаев соседних регионов и страны в целом.

Большие надежды связываются в будущем не только с возможностями освоения недавно разведанных медно-никелевых месторождений Воронежской области, но и нетрадиционными для Черноземья видами сырья, минерально-сырьевая база которых в других регионах исчерпывается. Это стекольное, агрохимическое сырье, различные сорбенты, глаукониты, полезные ископаемые вмещающих и вскрышных пород ряда месторождений, в первую очередь, железорудных. Наибольшее экономическое значение среди неметаллов имеют разнообразные месторождения строительных материалов, представленные как породами кристаллического фундамента, так и осадочного чехла Воронежской антеклизы (табл.1).

Таблица 1

Неметаллические полезные ископаемые ЦЧР

\begin{tabular}{|c|c|c|c|}
\hline $\begin{array}{c}\text { Типы } \\
\text { минерального сырья }\end{array}$ & $\begin{array}{c}\text { Виды } \\
\text { минерального сырья }\end{array}$ & Породы & $\begin{array}{l}\text { Примеры месторож- } \\
\text { денний, *проявлений }\end{array}$ \\
\hline Строительное & $\begin{array}{l}\text { Строительный камень: } \\
\text { скальных пород: } \\
\text { осадочных пород } \\
\text { Пески и гравий строительные } \\
\text { Цементное сырьё } \\
\text { Карбонатное (известь) } \\
\text { Кремнистое } \\
\text { Керамзитовое } \\
\text { Кирпично-черепичное }\end{array}$ & $\begin{array}{l}\text { Граниты } \\
\text { Кварциты и др. } \\
\text { Базальты } \\
\text { Доломиты } \\
\text { Известняки } \\
\text { Песчаники } \\
\text { Псаммиты, в т.ч. } \\
\text { Известняки } \\
\text { Мела } \\
\text { Карбонаты } \\
\text { Трепела, опоки } \\
\text { Суглинки, глины } \\
\text { Глины, суглинки, пески }\end{array}$ & $\begin{array}{l}\text { Шкурлатское (В), } \\
\text { Стойленское (Б) } \\
\text { *Мамонское (В) } \\
\text { Данковское (Л) } \\
\text { Донское (Л) } \\
\text { Бутурлиновское (В) } \\
\text { Ситовское (Л) } \\
\text { Елецкое (Л) } \\
\text { Белгородское (Б) } \\
\text { Хохольское (В) } \\
\text { Сапоговское (К) } \\
\text { Терновское (Б) } \\
\text { Железногорское (О) }\end{array}$ \\
\hline Керамическое & $\begin{array}{l}\text { Огнеупорное } \\
\text { Тугоплавкое } \\
\text { Каолины } \\
\end{array}$ & $\begin{array}{l}\text { Глины } \\
\text { Глины } \\
\text { Вторичные каолины } \\
\end{array}$ & $\begin{array}{l}\text { Латненское (B) } \\
\text { Б. Карповка (К) } \\
\text { Козынка (В) } \\
\end{array}$ \\
\hline $\begin{array}{l}\text { Металлургическое } \\
\text { (флюсы) }\end{array}$ & $\begin{array}{l}\text { Металлургическое, } \\
\text { Конверторное }\end{array}$ & $\begin{array}{l}\text { Доломиты }+ \\
\text { известняки }\end{array}$ & Данковское (Л) \\
\hline Сорбционное & $\begin{array}{l}\text { Бентонитовое } \\
\text { Цеолитовое }\end{array}$ & $\begin{array}{l}\text { Глины } \\
\text { Цеолитсодержащие } \\
\text { силициты и глины }\end{array}$ & $\begin{array}{l}\text { Никольское (В) } \\
\text { Хотынецкое (О) }\end{array}$ \\
\hline Агрономическое & $\begin{array}{l}\text { Фосфатное } \\
\text { Глауконитовое } \\
\text { Цеолитовое }\end{array}$ & $\begin{array}{l}\text { Фосфориты } \\
\text { Глауконит-кварцевые } \\
\text { пески } \\
\text { Цеолитсодержащие } \\
\text { силициты и глины }\end{array}$ & $\begin{array}{l}\text { Щигровское (К) } \\
\text { Центральное (Т) } \\
\text { Жерновец (К) }\end{array}$ \\
\hline Формовочное & $\begin{array}{l}\text { Песчаное } \\
\text { Глинистое }\end{array}$ & $\begin{array}{l}\text { Пески } \\
\text { Глины }\end{array}$ & Тамбовское (Т) \\
\hline Химическое & Мел & Мела & Логовское (Б) \\
\hline Стекольные пески & Песчаное & Кварцевые пески & Богдановское (В) \\
\hline Минеральные пигменты & Охристо-глинистое & Охры & Журавское (В) \\
\hline
\end{tabular}

Примечание: области: $E$ - Белгородская, $B$ - Воронежскся, $K$ - Курская, $Л$ - Липецкая, $O$ - Орловсая, $T$ - Тамбовская. 


\section{Строительное сырьё}

Щебень кристаллических пород является самым качественным его видом и производится из гранитов докембрия и вмещающих пород железорудных месторождений КМА. Строительные камни из осадочного чехла связаны с карбонатными породами верхнего девона, песчаниками апта и палеогена.

Всего в регионе Государственным балансом учтено 27 месторождений строительного камня, из которых эксплуатируется 17 месторождений [1]. В Воронежской области учтены три эксплуатируемых месторождения с запасами по категории $\mathrm{A}+\mathrm{B}+\mathrm{C}_{1}-384,7$ млн м ${ }^{3}, \mathrm{C}_{2}-145,7$ тыс. м³. На двух месторождениях Шкурлатовском и Тихий Дон разрабатываются граниты, которые отличаются высокими физико-механическими показателями. Марка бутового камня из них и щебня составляет 1200. Граниты пригодны для дорожного строительства, фундаментов зданий, брусчатки, бортовых камней, облицовочных плит и др. По конкурентоспособности месторождения данного вида сырья не имеют аналогов ни в регионе, ни и в центральной полосе России вплоть до Балтийского щита.

Уникальное Шкурлатовское месторождение с запасами гранитов категорий $\mathrm{A}+\mathrm{B}+\mathrm{C}_{1}-373,6 \mathrm{mлн} \mathrm{м}{ }^{3}, \mathrm{C}_{2}$ - 143,2 тыс. м ${ }^{3}$ разрабатывается ОАО «Павловскгранит», производящем строительный щебень, который поставляет различным предприятиям России. В 2010 г. на Шкурлатовском и Участке Тихий Дон месторождениях было добыто 4,4 млн м ${ }^{3}$, в том числе запасов категории $\mathrm{C}_{2}-0,1$ млн м³. В 2011 году были защищены запасы по наиболее перспективному месторождению гранитов «Казинское», где они составляют по категории $C_{1}-108689$ тыс. м³ $C_{2}-185666$ тыс. м Большие перспективы Воронежской области по данному виду сырья связываются с территорией развития гранитов павловского комплекса. Также в Павловском районе Воронежской области имеются два участка месторождений гранита: «Русская Буйловка» и «Ждановский», содержащие граниты, сходные по структуре и свойствам с гранитами, добывающимися предприятием «Павловскгранит». Учитывая значительный дефицит качественного гранитного щебня, они представляют большой интерес для инвесторов.

В Белгородской области разведаны и учтены 4 месторождения с запасами по категории $\mathrm{A}+\mathrm{B}+\mathrm{C}_{1}$ в количестве 647,1 млн м ${ }^{3}$ и по категории $\mathrm{C}_{2}-130,2$ млн м ${ }^{3}$. Три из них - Лебединское, Коробковское и Стойленское разрабатываются. Строительные камни представлены кристаллическими сланцами, кварцитопесчаниками, амфиболитами, гранитогнейсами. При современных темпах добычи, составляющих около 450 тыс. м ${ }^{3}$ в год запасами строительных камней область обеспечена более чем на 100 лет.

Перспектив выявления в районе новых крупных месторождений строительного камня не имеется, но удовлетворить потребности промышленности можно за счет его попутного извлечения при эксплуатации железорудных месторождений открытым способом. Во вскрыше и вмещающих породах Лебединского,
Стойленского, Коробковского, Чернянского и Погромецкого месторождений находится 951,1 млн м каменного материала, в том числе кристаллических сланцев 780,3, слаборудных кварцитов 17,7 , дайковых пород 36,0 , гранитов 54,4 , кварцитопесчаников 38,3 , амфиболитов и кварцевых порфиров $15,2 \mathrm{~m}^{3}$. Попутная добыча каменных материалов даст возможность полного обеспечения промышленности в этом сырье, при одновременной утилизации отходов горнорудного производства.

В Курской области имеется месторождение строительных камней во вмещающих породах Михайловского железорудного месторождения. Полезная толща представлена малорудными и безрудными кварцитами, кварцевыми порфирами, метапесчаниками, конгломератами, кварц-серицитовыми сланцами, пригодными для производства строительного щебня и бутового камня. Государственным балансом по категории $\mathrm{A}+\mathrm{B}+\mathrm{C}_{1}$ запасы учтены в объеме 67,0 млн м ${ }^{3}, \mathrm{C}_{2}-$ 106,1 млн м ${ }^{3}$. Месторождение разрабатывается. Часть попутно добываемых окисленных железистых кварцитов перерабатывается в щебень, используемый в дорожном строительстве. В 2010 г добыча окисленных железистых кварцитов составила 5,6 млн м ${ }^{3}$ и $\mathrm{C}_{2}$ $-0,7$ млн м ${ }^{3}$.

Важным полезным ископаемым являются базаль$m b l$, из которых можно получать балластный щебень, крайне дефицитный в ЦФО. Он используется при строительстве железных дорог и завозится из других регионов. Базальты могут залегать как во вскрыше медно-никелевых месторождений, так и в виде отдельных полей за их пределами (рис. 1, 2). Базальты Мамонской площади занимают $612 \mathrm{kм}^{2}$. Мощность базальтов - 0,2-203 м, в среднем 19,1 м, глубина залегания от 13 до 203 м от дневной поверхности. Общие запасы базальтов в Южно-Воронежской зоне 11689 млн м ${ }^{3}$, невыветрелых - 6504 млн м³. Над Нижнемамонским месторождением средние глубины 25,6 м и запасы больше 80 млн т базальтов. При производительности около 5 млн т в год, как Павловского ГОКа, запасов базальтов хватит на сотни лет. На Подколодновской площади глубина до пород фундамента десятки метров, но запасы более 0,5 млрд т. Т.е. на базе базальтов вскрыши медно-никелевых месторождений возможно создание крупного производства балластного щебня.

Месторождения строительного камня из осадочных пород имеются во всех областях и связаны с породами девонской, меловой, палеогеновой систем. Месторождения эксплуатируются на щебень и бут, как заполнители для бетонов, а также в асфальтобетоне при строительстве дорог.

В Орловской области месторождения строительных камней приурочены к верхнедевонским известнякам, реже доломитам, пригодным, в основном, для неморозостойкого бута марки «200», щебня для обычного бетона марок «100-400» в конструкциях, не подвергающихся замораживанию и оттаиванию, для строительства автодорог местного значения. Все существующие 


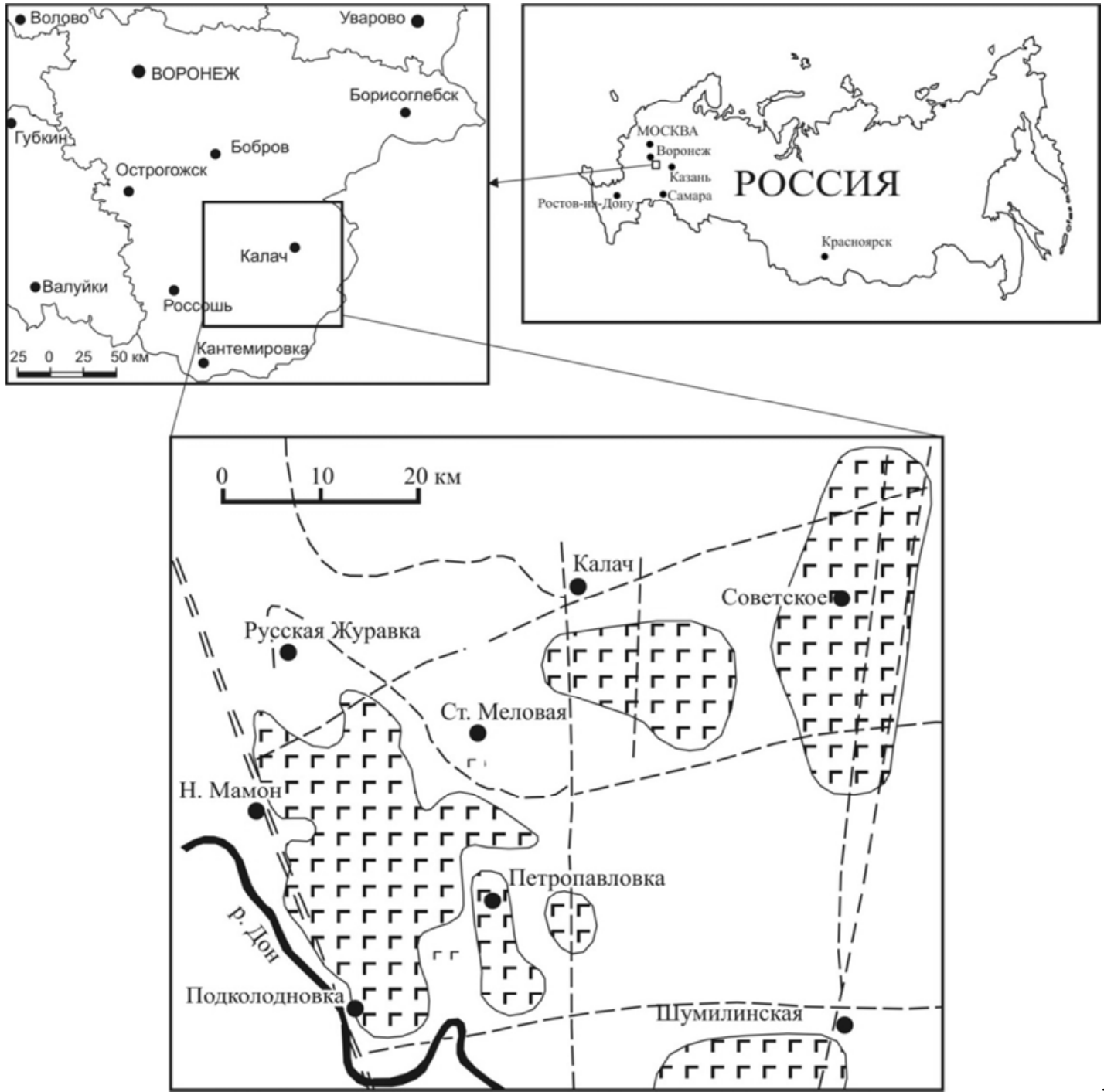

Puc. 1. Схема расположения полей развития базальтов. Условные обозначения см. рис. 2.

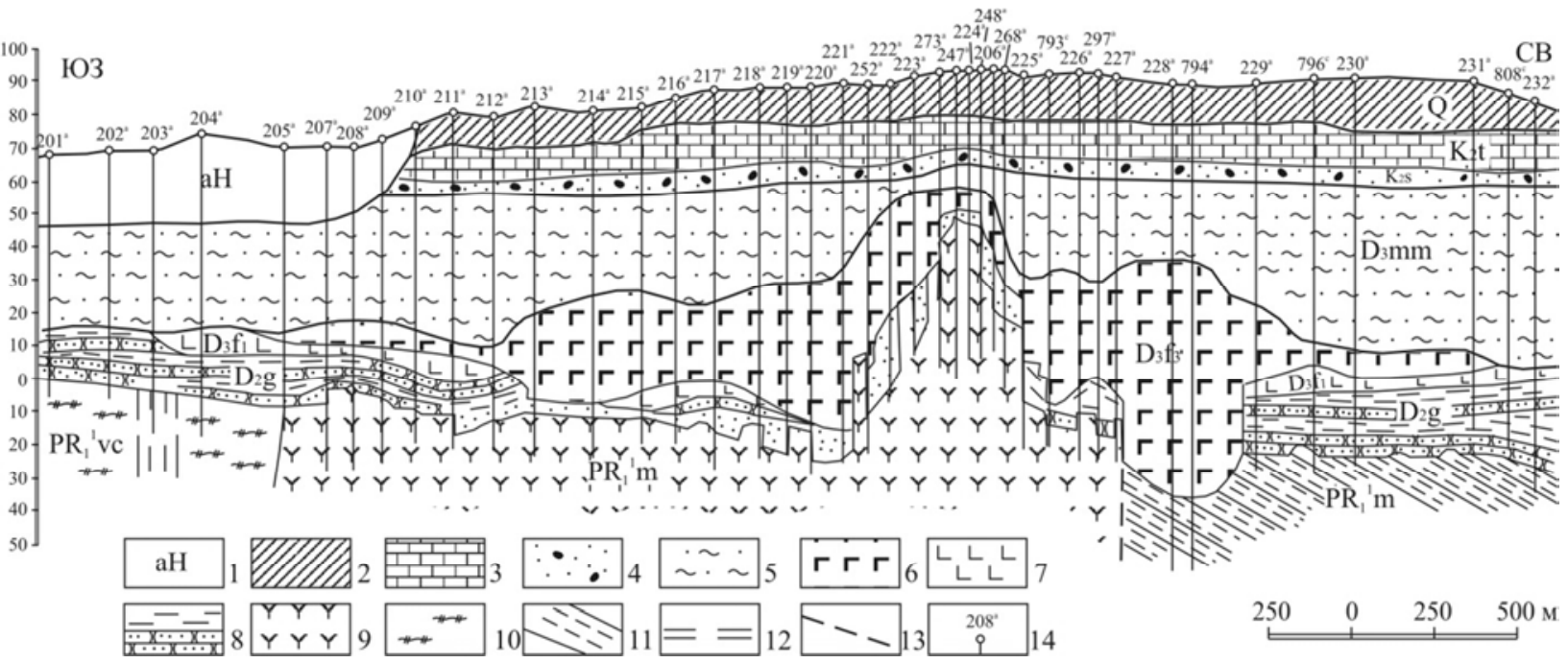

Puc. 2. Геологическиий разрез осадочного чехла района Подколодновского медно-никелевого месторождения. Условные обозначения: 1 - современный аллювий; 2 - покровные суглинки; 3 - мел $\left(\mathrm{K}_{2} \mathrm{t}\right) ; 4$ - песок с желваками фосфоритов; 5 - песчанокаолиновая толща $\left(\mathrm{D}_{3} \mathrm{f}_{3}-\mathrm{fm}_{2}\right) ; 6$ - базальты $\left(\mathrm{D}_{3} \mathrm{f}_{3}\right) ; 7$ - песчано-глинистые отложения $\left(\mathrm{D}_{3} \mathrm{Zv}\right) ; 8$ - ультраосновные породы мамонского комплекса $\left(\mathrm{PR}_{1}{ }^{1} \mathrm{~m}\right) ; 9$ - туффиты $\left(\mathrm{D}_{3} \mathrm{f}_{3}\right) ; 10$ - гнейсы воронцовской серии $\left(\mathrm{PR}_{1}{ }^{1} \mathrm{vc}\right) ; 11$ - сланцы воронцовской серии $\left(\mathrm{PR}_{1}{ }^{1} \mathrm{vc}\right) ; 12-$ Лосевско-Мамонская зона разломов; 13 - линейные зоны разломов; 14 - скважина и ее номер. 
горнодобывающие предприятия в области обеспечены разведанными запасами на длительный срок. Потребность области в каменных стройматериалах не удовлетворяется полностью за счет местного производства. Крепкие разности ввозятся из других областей.

Липецкая область располагает значительными запасами строительных камней. Месторождения их приурочены к верхнедевонским (известняки и доломиты), а также к нижнемеловым (песчаники) отложениям. Они широко развиты по площади и залегают неглубоко от поверхности. Разведано 7 месторождений строительного камня с общими запасами по категориям $\mathrm{A}+\mathrm{B}+\mathrm{C}_{1}-235,9$ млн $\mathrm{m}^{3}, \mathrm{C}_{2}-92,2$ млн м ${ }^{3}$. Наиболее крупными месторождениями известняков являются: Аргамачское $\left(34,7\right.$ млн м $\left.^{3}\right)$, Тюшевское $\left(37,7\right.$ млн м $\left.{ }^{3}\right)$, Черкасское $\left(137,5\right.$ млн м $\left.{ }^{3}\right)$, Ериловское $\left(70,2\right.$ млн м $\left.{ }^{3}\right)$. К крупным месторождениям доломитов относятся Правобережное и Бугровское. В настоящее время в эксплуатацию вовлечены 6 месторождений, что позволяет вывозить среднепрочный щебень из Липецкой в остальные области ЦЧР. Кроме указанных месторождений, выявлено 9 участков строительного камня (7 - известняков, 1 - доломитов и 1 - песчаников). Общие авторские запасы и прогнозные ресурсы известняков составляют по $\mathrm{C}_{1}-110,9, \mathrm{C}_{2}-1,7$, $\mathrm{P}_{1}-380, \mathrm{P}_{3}-17$; доломитов - 82,9; песчаников - 0,8 млн $\mathrm{M}^{3}$. Прогнозные ресурсы доломитов БигильдиноНикольской площади около 98,2 млн м³.

Карбонатные строительные камни Тамбовской области представлены двумя учтенными государственным балансом Иловайским-II и Борисовским месторождениями девонских известняков с балансовыми запасами по категории $\mathrm{A}+\mathrm{B}+\mathrm{C}_{1}-12,0$ и $\mathrm{C}_{2}-5,4$ млн $\mathrm{M}^{3}$. В пределах области имеется несколько участков этого вида сырья, не учтенных Госбалансом, с разве- данными запасами по категориям $\mathrm{C}_{1}-9,7$ млн м ${ }^{3}, \mathrm{C}_{2}-$ 52,0 млн м ${ }^{3}$. Отмечается острый дефицит производства местных каменно-строительных материалов, нарастающий из года в год. Перспективными для разведки и эксплуатации являются породы елецкого, лебедянского, плавского и озерского горизонтов девона. В Воронежской области разрабатывается Кривоборское месторождение известняков с запасами по $\mathrm{A}+\mathrm{B}+\mathrm{C}_{1}-11,1$ млн м ${ }^{3}$.

Пески строительные. Имеют ведущее значение для отрасли, а наиболее ценными считаются песчаногравийные смеси, пригодные в качестве заполнителя в бетон. Они известны во всех областях. Их месторождения обычно приурочены к аллювиальным отложениям рек преимущественно первой и второй надпойменным террас. Но обычно пески мелкозернистые, с повышенным содержанием глинистых частиц, пригодны для получения бетона марок не выше 200, иногда с перерасходом цемента до 10-15 \%. Модуль крупности песков 1,1-1,5, редко до 2 .

В пределах ЦЧР известно 115 учтенных государственным балансом месторождений строительных песков (табл. 2), из которых 78 эксплуатируется преимущественно предприятиями промышленности строительных материалов. Примерно такое количество их неучтенных, значительная часть которых разрабатывается. Пески пригодны для строительных работ, дорожного строительства, производства силикатных изделий, ячеистого бетона, асфальтобетона, штукатурных и кладочных растворов. Большая часть песков используется для приготовления бетонов, при этом перерасход цемента составляет 10-15 \% в зависимости от марки бетона. Как правило, пески каждого месторождения могут использоваться для различных строительных производств [2].

Таблица 2

Распределение месторождений строительных песков по областям ЦЧР

\begin{tabular}{|l|c|c|c|c|c|}
\hline \multicolumn{1}{|c|}{ Область } & $\begin{array}{c}\text { Всего место- } \\
\text { рождений }\end{array}$ & $\begin{array}{c}\text { Разраба- } \\
\text { тываемых }\end{array}$ & $\begin{array}{c}\text { Песчано-гравий- } \\
\text { ные смеси }\end{array}$ & $\begin{array}{c}\text { Пески для сили- } \\
\text { катных изделий }\end{array}$ & $\begin{array}{c}\text { Пески для др. ви- } \\
\text { дов строительства }\end{array}$ \\
\hline Белгородская & 15 & 13 & - & 11 & 4 \\
\hline Воронежская & 24 & 17 & 1 & 5 & 18 \\
\hline Курская & 16 & 12 & 1 & 4 & 10 \\
\hline Липецкая & 18 & 14 & - & 4 & 20 \\
\hline Орловская & 29 & 15 & 5 & 7 & 6 \\
\hline Тамбовская & 13 & 7 & 2 & 35 & 71 \\
\hline ЦЧР в целом & 115 & 78 & 9 & & \\
\hline
\end{tabular}

В качестве бетонных (песчано-гравийные смеси) числятся 9 месторождений песков, из которых эксплуатируется только 5. Перспективы выявления промышленных месторождений этих песков ограничены, хотя не исключена возможность обогащения песков известных месторождений, пригодных в качестве штукатурных и кладочных, путем отсева частиц менее 0,14 мм. Возможно использование песков, залегающих во вскрыше железорудных месторождений, также путем отсева мелких фракций, но в этом случае необходима добавка некоторого количества грубозер- нистой фракции. Перспективы по выявлению новых промышленных месторождений песчано-гравийной смеси незначительны, так как большинство русловых отложений к настоящему времени хорошо изучено.

Пески, пригодные для строительных целей в качестве заполнителя в штукатурных, кладочных расmвopax, а также для закладки выработанного пространства подземных рудников, известны в мезокайнозойских отложениях. Наиболее удовлетворительны по качеству пески квартера. Они слагают аллювий первой, второй, иногда третьей надпойменной террас 
рек и особенно р. Дон.

Пески палеогена связаны с отложениями полтавской серии и отличаются преобладанием тонкозернистой и пылеватой фракций. Они пригодны к использованию при гидравлической закладке выработанных пространств, строящихся подземных рудников. Пески альбского, сеноманского ярусов меловой и юрской систем могут использоваться попутно при отработке вскрыши железорудных месторождений, они характеризуются высоким качеством и значительными запасами.

Месторождения песков, пригодных для получения силикатного кирпича и изделий из силикатного бето$н a$, известны в юрских, меловых, палеогеновых и четвертичных отложениях. Качество песков всех отложений примерно одинаково. Всего разведано 35 месторождений песков для силикатных изделий, из которых 17 эксплуатируется (табл.2). Перспективы выявления других месторождений сырья, пригодного для получения силикатного кирпича и силикатных изделий, в регионе имеются. Для этих целей можно использовать пески полтавских и харьковских отложений палеогена, которые залегают во вскрыше Лебединского, Михайловского, Стойленского, СтойлоЛебединского, Погромецкого, Коробковского и Чернянского месторождений. Их запасы оцениваются в пределах 1,2-1,5 млрд м ${ }^{3}$.

Цементное сырьё. В пределах региона известно 9 месторождений цементного сырья, на базе которых работают четыре цементных завода: Липецкий (Coкольско-Ситовское месторождение), Белгородский (месторождения Полигон, Черная Поляна), Старооскольский (вскрыша Стойленского железорудного месторождения), Подгоренский (Подгоренское месторождение). Запасы и ресурсы по областям ЦЧР распределены неравномерно. В наилучшем положении находятся Белгородская, Воронежская и Липецкая области. Конкурентоспособность по данному виду сырья в сравнении с другими регионами страны велика.

В качестве карбонатного компонента используются фаменские известняки девона, мел и мергель верхнего отдела меловой системы в шихте мел + мергель или мел + глины, а также мергель-натурал (Подгоренское месторождение). Глинистым компонентом обычно служат четвертичные глины и суглинки, иногда для корректировки шихты используются глинистые породы из коры выветривания сланцев (Лебединское месторождение железных руд). Марка цемента из шихты мел + четвертичные глины достигает 500, а из шихты мергель + мел -600 .

Белгородская область располагает значительными запасами цементного сырья - мела, глин и суглинков, выветрелых сланцев. Государственным балансом учтено два месторождения глинистых и карбонатных пород. Это Стойленское и Белгородское месторождения, с общими запасами по состоянию на 01.01.2011 года: мела по категориям $\mathrm{A}+\mathrm{B}+\mathrm{C}_{1}-475,6$ млн т, по категории $\mathrm{C}_{2}-149,9$ млн т; глин и суглинков по категориям $\mathrm{A}+\mathrm{B}+\mathrm{C}_{1}-73,4$ млн т, по категории $\mathrm{C}_{2}-61,1$ млн т; выветрелых сланцев - по категориям $\mathrm{B}+\mathrm{C}_{1}-6,9$ млн т. Кроме того, запасы спецотвала мела составляют 123,6 млн т [3].

В настоящее время отработку указанных месторождений ведут три горнодобывающих предприятия: ОАО «Стойленский ГОК», ЗАО «ОсколцеменТ» и ЗАО «Белгородский цемент». Суммарная добыча цементного сырья составляет свыше 12 млн т. Заводы выпускают портландцемент марок 400-500. Цемент используется для нужд области и выводится за ее пределы. Пригоден для цементной промышленности в качестве карбонатной составляющей мел вскрыши Лебединского, Стойло-Лебединского, Погромецкого, Чернянского, резервного Приоскольского месторождений с запасами в сотни миллионов тонн. Имеются также огромные ресурсы карбонатных и глинистых пород для цементной промышленности в других районах области с меньшей техногенной нагрузкой.

В Воронежской области разведано крупное Подгоренское месторождение цементного сырья с запасами карбонатных пород (мел, мергель) по категориям $\mathrm{A}+\mathrm{B}+\mathrm{C}_{1}-382,112$ млн т, $\mathrm{C}_{2}-396,8$ млн т. В строении месторождения принимают участие сантонкампанские отложения верхнемеловой системы, пески и кремнистые глины палеогена локальные останцы песчано-глинистых образований неогена и покровные суглинки четвертичного возраста. Продуктивная толща приурочена к верхней части сантонского яруса и представлена чередованием глинистых, слабо кремнеземистых и мелоподобных мергелей общей мощностью от 8,0 до 33,2 м (средняя - 16,25 м). Благоприятным природным сырьем для производства цемента, требующим минимума корректирующих добавок, являются мергели-натуралы подгорненской свиты верхнего сантона с содержанием $\mathrm{CaCO}_{3} 78-80 \%$. На литолого-фациальной карте сантонского века, выделены зоны преимущественного развития мергелейнатуралов [4], в пределах одной из которых и расположено Подгоренское месторождение цементных мергелей. Литологами ВГУ выделен ряд перспективных поисковых площадей на сырье, пригодное для производства высококачественных сортов цемента.

В Курской области цементное сырье разведано на 6 месторождениях с общими запасами 183,0 млн м ${ }^{3}$. На баланс поставлены 4 месторождения. РусскоКонопельское месторождение мела и Пушкарское месторождение суглинков находятся в Суджанском районе. В таких же благоприятных условиях находятся месторождения в Солнцевском районе (Солнцевсое II мела и мергелей «Машнино»). Технологическими испытаниями мела + суглинки и мела+мергели с использованием добавок получен цемент, отвечающий требованиям для марок 500 и выше. Балансовые запасы сырья на этих месторождениях 172 млн т. Имеются перспективные участки с цементным сырьем в Курском и Щигровском районах.

На территории Липецкой области балансом на 01.01.2011 г. учтены 2 месторождения цементного сырья (Сокольско-Ситовское и Чибисовское) с запа- 
сами по категориям $\mathrm{A}+\mathrm{B}+\mathrm{C}_{1}-140,5$ млн т. Сырье представлено верхнедевонскими известняками (карбонатный компонент) и глинами аптского, суглинками четвертичного возраста (глинистый компонент). Учитывая современные темпы ежегодной отработки цементного сырья, составляющие около 2 млн т, Липецкая область обеспечена им почти на 70 лет. Цемент также отгружается в Воронежскую, Тамбовскую, Орловскую, Ярославскую, Курскую, Московскую, Пензенскую, Волгоградскую области.

Карбонатное сырьё. Большинство месторождений карбонатных пород, в том числе мела, описание которых приводилось ранее, можно рассматривать как строительное сырье. Мел в качестве карбонатных пород, распространенный в Воронежской, Белгородской и Курской областях практически всех месторождений, пригоден в качестве сырья для производства строительной извести, мела дробленого, комового или молотого. В Воронежской области государственным балансом запасов учтено 12 месторождений мела, в Белгородской 20 с общими запасами по категориям $\mathrm{A}+\mathrm{B}+\mathrm{C}_{1}-836580$ тыс. т. В Курской области на 10 месторождениях строительной извести запасы составляют по $\mathrm{A}+\mathrm{B}+\mathrm{C}_{1}-61350$ тыс. т, в Орловской области учтено Турушкинское месторождение мела для производства строительной извести, суммарные запасы которого по категориям $\mathrm{A}+\mathrm{B}+\mathrm{C}_{1}$ составляют 11599 тыс. т. Готовая продукция (известь) поставляется силикатным заводам перечисленных областей и других субъектов России.

Карбонатные породы верхнего отдела девонской системы, применяемые в строительной отрасли, развиты в Липецкой, Орловской и Тамбовской областях. В первой разведано 10 месторождений этого сырья для производства строительной извести с общими запасами 38,6 млн т по категориям $\mathrm{A}+\mathrm{B}+\mathrm{C}_{1}$. Из них 7 учтены балансом с суммарными запасами 20,9 млн т (Самовецкое, Елецкое, Аргамачское, Барановское, Воргольское, Трубицкое, Ивановское), 3 (Малые Борки, Кизинское, Лебедянское) имеют авторские запасы 17,7 млн т. В настоящее время на территории области разрабатываются Самовецкое и Елецкое месторождения. Основными потребителями извести являются заводы силикатного кирпича и предприятия стройиндустрии Липецкой, Пензенской и Тамбовской областей.

Кремнистое сырьё (силициты). Представлено трепелами и опоками, верхнего отдела меловой и палеогеновой систем. Всего в ЦЧР учтено девять месторождений, из которых два эксплуатируются. Перспективы для выявления новых промышленных месторождений благоприятные [5-7].

В Орловской области разведаны два крупных месторождения трепелов - Хотынецкое и Красноозерское, первое из них эксплуатируется не только на кремнистое, но и цеолитовое сырьё [2]. Трепелы мощностью 4,5-24 м приурочены к турон-коньякским отложениям, перекрыты четвертичными суглинками мощностью 2,5-13 м. Из сырья получают трепельный гравий и обжиговый трепельный песок марок 900-1000, используемые в качестве высокопрочных бетонов.

В Липецкой области, в Тербунском районе, недавно разведано Михайловское месторождение, сложенное кремнистыми глинами сантонского яруса мощностью до 19 м. Оно разрабатывается для получения легковесного кирпича марки не ниже 75 и трепельного гравия марок 300-600, производства кормовых добавок и сорбентов. Его запасы по $\mathrm{C}_{2} 12498$, по $\mathrm{P}_{1}$ 42642 тыс. м ${ }^{3}$. В Курской области имеются два месторождения трепела, суммарные запасы которого 4705 тыс. м $^{3}$.

В Белгородской области опоки киевской свиты палеогена со средней мощностью 8,4 м слагают месторождение Кладовое в Губкинском районе. Они перекрыты четвертичными суглинками $(1,0-13,0$ м). Из опок получен термолитовый щебень, конструктивноизоляционный термолитобетон, стеклокерамические изделия, пигментно-цементные плитки, гидравлические добавки.

В Тамбовской области, где месторождения на балансе ТГФ не числятся, выявлено Краснослободское месторождение трепелов с запасами по категории $\mathrm{C}_{1}-$ 2,8 млн м ${ }^{3}$ и два участка с предварительно оцененными суммарными запасами категории $\mathrm{C}_{1} 8,3$ млн м³. Полезная толща представлена пластообразной залежью опоковидных глин, трепеловидных и опоковидных алевритов и других разностей кремнистых пород сантонского яруса верхнего мела. Выявленное в пределах области сырье пригодно только для производства тяжелых наполнителей бетонов. Обширные площади востока Тамбовской области с широко развитыми кремнистыми породами верхнего мела заслуживают дальнейшего изучения.

Керамзитовое сырье. Им служит преимущественно четвертичные глины и суглинки, палеогеновые и юрские глины. Первые вспучиваются при добавке 0,5-2 \% органики в виде опилок, угля, солярового масла и дают керамзит марки 500-700 по насыпной объемной массе (Курский, Белгородский, Воронежский керамзитовые заводы). Юрские глины вспучиваются в естественном виде, полученный из них керамзит характеризуется более высокими марками, но их месторождения известны только в Орловской области. В палеогене имеются киевские керамзитовые глины, гравий из которых характеризуется хорошими технологическими свойствами - малым объемным весом, но эти глины требуют добавки органики [2].

Всего учтено 25 месторождений керамзитовых глин, из которых 10 эксплуатируется керамзитовыми заводами. Все месторождения по запасам относятся к крупным и средним. Самым крупным является Терновское с запасами 11,4 млн м 3 , эксплуатируемое Белгородским керамзитовым заводом. Перспективы выявления новых месторождений керамзитового сырья в четвертичных отложениях на изученной территории удовлетворительные. Значительным резервом для получения керамзита являются четвертичные глины и суглинки, залегающие во вскрыше Коробковского и Стойло-Лебединского железорудных месторождений. 
Предварительные испытания их на вспучиваемость дали хорошие результаты. Для аглопорита пригодны глины и суглинки, используемые в керамзитовом производстве или характеризующиеся даже худшими технологическими показателями.

Кирпично-черепичное сырьё. В качестве кирпичного сырья на территории Черноземья разведаны преимущественно четвертичные суглинки и глины элювиально-делювиального, аллювиального и озерно-ледникового генезиса [8]. Полезная толща на месторождениях имеет пластообразную форму и выдержана по простиранию. Ее мощность иногда достигает 20-27 метров, но на большинстве месторождений составляет 8 12 м. Месторождения отличаются относительной простотой геологического строения, благоприятными горнотехническими условиями для разработки открытым методом. Сырье пригодно для получения кирпича марки 75-150, редко 200, как в естественном виде, так и с добавкой в качестве отощителя песков, шлака, дегидратированной глины, иногда молотого угля.

Известны месторождения, полезная толща которых связана с киевской свитой палеогена или представлена юрскими глинами. Марка кирпича из этих глин несколько выше, а кирпич характеризуется более светлой окраской. Всего известно 386 месторождений кирпично-черепичного сырья с запасами в многие сотни миллионов тонн, из которых 152 эксплуатируется кирпичными заводами, в том числе 11 песковотощителей [2]. В Воронежской области разрабатывается 26 , в Курской - 34. Липецкой - 17, Белгородской - 36, Тамбовской - 33, Орловской 6 месторождений.
Большинство из них малые по запасам, 24 - средние по запасам и 4 - Железногорское, Дорожное, Новоусманское II, Стрелицко-Латненское - крупные. Возможности выявления новых месторождений на изученной территории не ограничены, так как четвертичные глины и суглинки широко распространены. Имеется также реальная возможность использования кирпичных суглинков, залегающих во вскрыше железорудных месторождений.

\section{Керамическое сырьё}

К керамическому сырью относятся огнеупорные, тугоплавкие, легкоплавкие глины, а также каолины. Легкоплавкие глины и суглинки рассмотрены нами выше при характеристике кирпично-черепичного сырья. Среди каолинов могут быть как огнеупорные, так и тугоплавкие разности, поэтому в силу их специфики и использования в качестве многих других видов неметаллического сырья они рассматриваются отдельно.

Огнеупорные глины на территории ЦЧР известны лишь в Латненском месторождении Воронежской области. Оно расположено в Семилукском и Хохольском районах (рис. 3). Эти глины приурочены к аптскому ярусу нижнего мела и хорошо изучены [9-13]. Балансовые запасы огнеупорных глин месторождения на сегодняшний день составляют чуть более 36 млн т по категориям $\mathrm{B}+\mathrm{C}_{1}+\mathrm{C}_{2}$, прогнозные $\mathrm{P}_{1}-9,2$ млн т, забалансовые - 36 млн т. Месторождение разрабатывается ОАО «Воронежское рудоуправление». Производимая продукция - огнеупорная глина для металлургической промышленности. Потребителями сырья

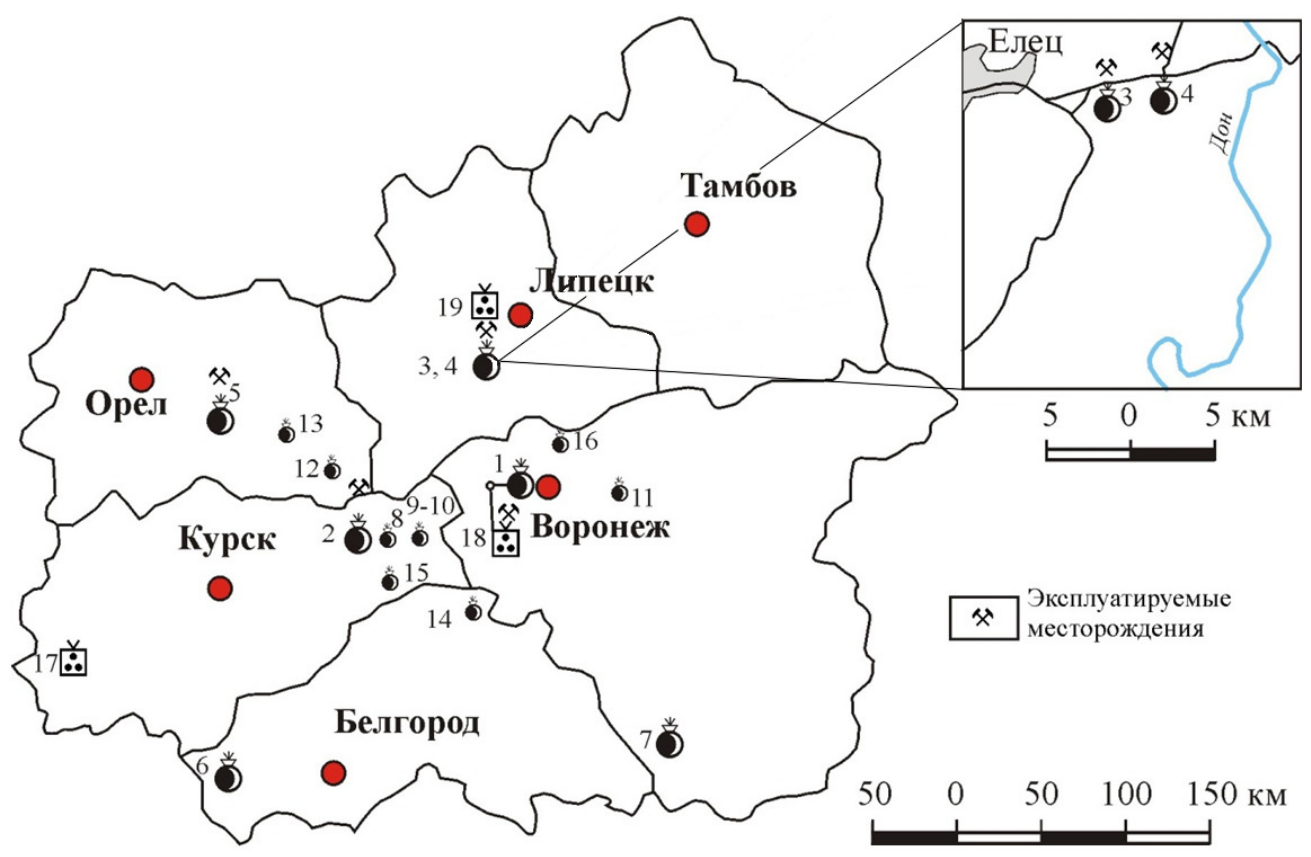

Puc. 3. Схема расположения месторождений и проявлений керамических глин и стекольных песков ЦентральноЧерноземного района: 1-7 - месторождения керамических глин, учтенные Государственным балансом запасов: $1-$ Латненское, 2 - Большая Карповка, 3 - Лукошкинское, 4 - Чибисовское, 5 - Малоархангельское, 6 - Краснояружское, 7 - Шрамовское; 8-16 месторождения, не учтенные Государственным балансом запасов: 8 - Касторенское (Николаевская залежь), 9 - Горяиновское, $10-$ Нижнетуровское, 11 - Криушанское, 12 - Плешковское, 13 - Беречка, 14 - Сергиевское, 15 - Горшеченское, 16 - Байгорское; $17-19$ - месторождения стекольных песков, учтенные ГКЗ или ТКЗ: 17 - Секеринское, 18 - Богдановское, 19 - Федоровский участок Сенцовского месторождения. 
являются Семилукский, Латненский, Подольский и другие огнеупорные заводы России. В настоящее время 2/3 продукции вывозится за пределы области. Основными потребителями являются металлургические, цементные и керамические производства Тульской, Липецкой и Ленинградской областей. Увеличение балансовых запасов Латненского месторождения возможно за счет залежей огнеупорных глин на участках поисков Левобережья и Правобережья реки Девица. Обнаружение новых залежей возможно к северу и северо-западу от железнодорожной станции Латная в Семилукском районе, что актуально на современном этапе. При сложившейся ситуации, когда месторождение большей частью выработано и существующих темпах производства запасов сырья может хватить примерно на 25 лет.

Дефицит керамических заводов России в глинах может быть перекрыт за счет Криушанского месторождения, расположенного в Аннинском районе Воронежской области. Оно состоит из двух залежей, степень изученности которых отличается. Запасы по Зеленовской залежи по категории $\mathrm{C}_{1}$ составляют 53,5 млн т, в том числе основных высококачественных сортов - 33,9 млн т, Романовской залежи запасы по $\mathrm{C}_{2}$ 42,2 , основных сортов 22,44 млн т. Основным препятствием является большая мощность вскрыши 85-89 м, при мощности полезной толщи от 1 до 10 м и обводненность большей части вскрыши и всей полезной толщи. При перспективном введении месторождения в разработку можно было бы обеспечить производительность до 500 тыс. т. в год.

Тугоплавкие глины. На исследуемой территории известно 14 месторождений тугоплавких глин (рис. 3), которые составляют примерно $15 \%$ всех запасов России. Из них Лукошкинское, Чибисовское, Малоархангельское, Большекарповское, в небольшой степени Краснояружское, эксплуатируются $[12,14]$.

В пределах ЦЧР проявления тугоплавких глин встречены в отложениях практически всех систем фанерозоя, но месторождения обнаружены в породах апта, эоцена, олигоцен-миоцена и плиоцена. Основная часть запасов сосредоточена в аптских образованиях. Сухарные глины карбона встречены и изучены во вскрыше Погромецкого железорудного месторождения, которое подлежит эксплуатации открытым методом. Они имеют огнеупорность 1600-1750 и местами интенсивно ожелезнены. Проявления светло-серых тугоплавких глин в юрских отложениях известны в Орловской области, но ввиду линзовидного залегания и небольших запасов промышленного значения они не имеют. Аптские глины меловой системы известны в Орловской, Курской, Липецкой и Воронежской областях. Они характеризуются высокой огнеупорностью и прекрасными технологическими свойствами. В отложениях палеогена имеются месторождения и проявления тугоплавких глин, связанные с киевской и палеоген-неогеновой пасековской свитами в пределах Белгородской и Воронежской областей. Тугоплавкие глины неогеновой системы развиты в Орловской, Белгородской, Воронежской областях, вероятно, их наличие и в Курской области [15]. Глины имеют пестрый состав и разнообразные технологические свойства, огнеупорность их изменяется от 1380 до $1700^{\circ} \mathrm{C}$, и они пригодны для различных изделий, в том числе и для лицевого кирпича.

Перспективы выявления новых месторождений огнеупорных и тугоплавких глин на территории ЦЧР удовлетворительные, необходима постановка поисково-оценочных работ на это сырье. В этом плане наиболее привлекательными представляются территории развития аптских образований Липецкой, Орловской и северной части Курской областей, где имеются разрабатываемые месторождения и обнаружен ряд проявлений глин с хорошими технологическими свойствами.

Kаолины. Вторичные каолины мамонской толщи верхнего девона известны с середины прошлого столетия и описаны в ряде работ [16-18 и др.]. Все их авторы предполагали наличие месторождений в этой толще, образованной за счет размыва древних кор выветривания пород кристаллического фундамента докембрия. Но первое месторождение с авторскими запасами около 18 млн т было разведано только в 2017 году. Учитывая отсутствие каолинов практически на всей территории Европейской части Российской федерации, полученные данные предполагают открытие новой каолиноносной провинции, позволяющей обеспечить этим сырьём многие предприятия рассматриваемого региона.

Песчано-каолиновая толща протягивается полосой шириной порядка 60 км от г. Нового Оскола Белгородской до восточной границы Воронежской областей, имеет мощность от 10 до первых сотен метров и залегает на глубинах от первых до 200 м на водоразделах. Наиболее благоприятные близ поверхностные условия залегания толщи находятся в области Павловского неотектонического поднятия, где и следует сосредоточить поиски месторождений каолинов. Помимо глинистого компонента она содержит кварцевые зерна и гравий, являющиеся ценным строительным, а, возможно, и стекольным сырьём. Обломочные компоненты извлекаются при гидроклассификации. Рыхлые породы толщи позволяют вести их добычу высоко экологичным гидроскважинным способом.

\section{Металлургическое (флюсовое) сырьё}

В настоящее время на территории ЦЧР имеется только одно Данковское, самое крупное из 200 известных месторождений металлургических доломитов России. Его запасы только по категориям В+C составляют порядка 700 млн т, которые могут быть увеличены при проведении разведочных работ на перспективных участках. Месторождение связано с фаменскими карбонатными отложениями кудеяровских и тургеневских горизонтов верхнего девона, продуктивная толща имеет мощность около 40 м, вскрыша составляет от первых до 20 м (рис. 4). 


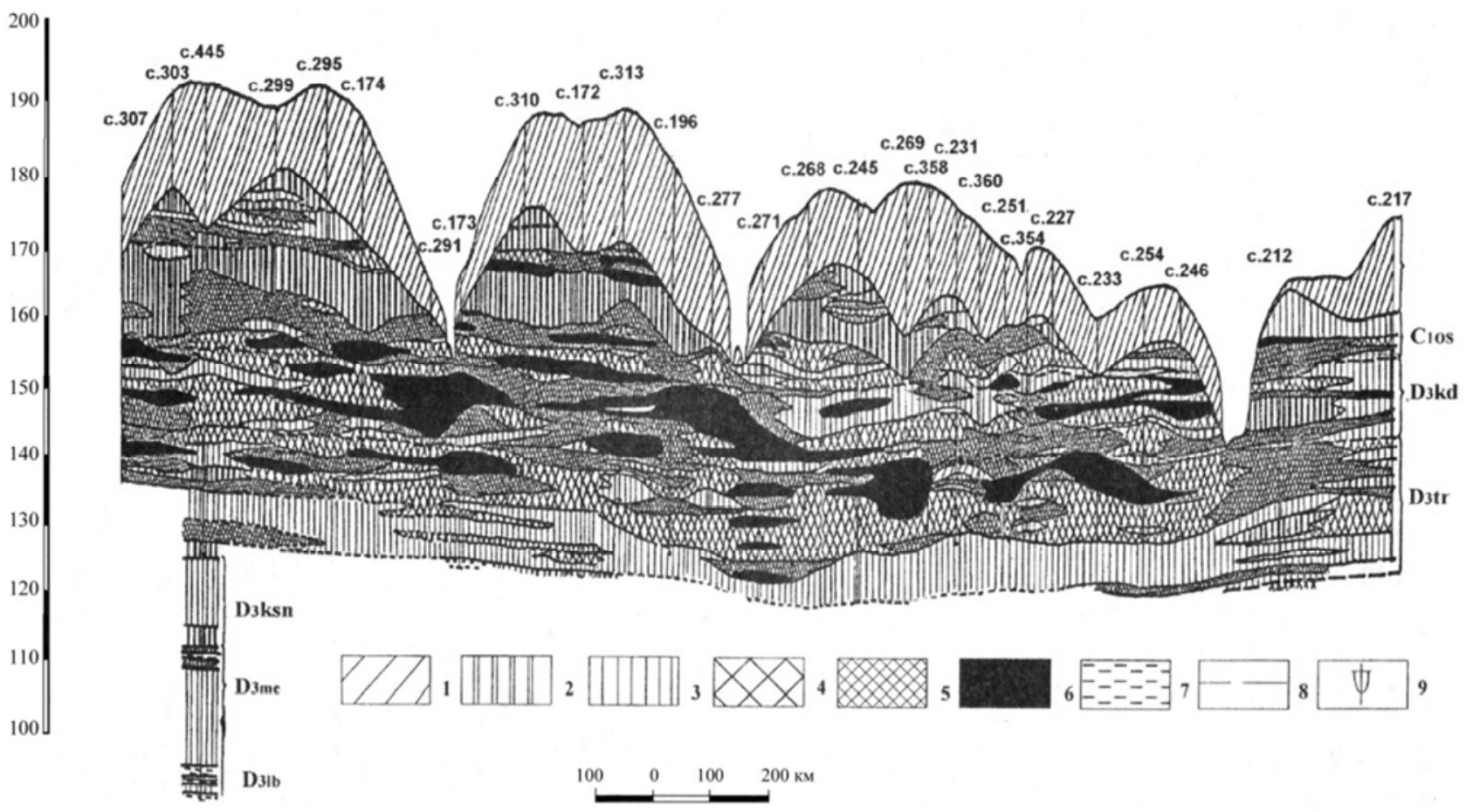

Puc. 4. Геологический разрез по линии I-I Данковского месторождения: 1 - четвертичные песчано-глинистые отложения; 2 - доломитовые мергели; 3 - доломитовые известняки; 4 - доломиты известковистые; 5 - доломиты; 6 - доломиты с повышенным содержанием MgO (конверторные); 7 - глины карбонатные; 8 - стратиграфические границы; 9 - карстовые зоны.

Конверторные доломиты разведаны на Золотухинском и Прикарьерном участках Данковского месторождения, где посчитано 20 млн т запасов. Это наиболее чистые и легкообогатимые разности, залегающие в средней части продуктивной толщи. Кроме того, выделен ряд площадей для их поисков [19]. Флюсовые известняки по технологическим параметрам должны быть наиболее чистыми и содержать не менее $50 \% \mathrm{CaO}$, не более $1,8 \% \mathrm{SiO}_{2}$ и 2,3\% $\mathrm{Al}_{2} \mathrm{O}_{3}$. Такие разности имеются в верхней части елецкого горизонта на территории Липецкой области. Кроме того, по данным фациального анализа выделены площади с подобными известняками в лебедянском горизонте [19], так что общие потенциальные ресурсы флюсовых известняков для промышленного освоения оцениваются примерно в 3,3 млрд тонн.

Конверторные известняки, приуроченные к елецкому горизонту, разведаны на Донском и Хмелиницком месторождениях в Липецкой области. Полезная толща в них представлена мощной толщей карбонатных пород с резко подчиненными прослоями доломитистых и глинистых известняков. По результатам фациального анализа и обработки химических и физикомеханических определений выделены три прогнозные площади. Породы на них сходны с породами Хмелинецкого месторождения. Всё это позволяет прогнозировать запасы конверторных известняков в первые миллиарды тонн.

Таким образом, месторождения флюсового сырья для металлургической промышленности позволяют не только обеспечить им ЦЧР, но и быть крупным его экспортером в другие регионы России.

\section{Сорбционное сырьё}

К сорбционному сырью на территории ЦЧР относятся бентонитовые глины, силициты (диатомиты, трепела и опоки) и цеолитсодержащие породы. Большие потребности ЦЧР в бентонитовых глинах связаны с нарушением экономических связей с традиционными поставщиками (Закавказские республики) и резким удорожанием дальних межгосударственных перевозок. Это вызывает необходимость создания местной сырьевой базы бентонитового сырья, тем более что все предпосылки для этого имеются и частично уже реализованы [20-22].

Бентониты, силициты и цеолитсодержащие породы представляют ценный природный материал, обладающий целым набором полезных свойств, таких как адсорбционная способность, высокая пористость, термостойкость, гидравлическая активность, химическая стойкость к кислотам и щелочам, что позволяет использовать его в различных отраслях народного хозяйства. Это сырье применяют в качестве гидравлических добавок, адсорбентов, теплоизоляционных и полировальных материалов, наполнителей, фильтров, катализаторов, для производства изделий из керамики, а также в строительной промышленности, сельском хозяйстве и т.д. Месторождения силицитов в качестве строительного сырья описаны выше и в настоящем разделе не рассматриваются. Породы из 
них могут использоваться и в качестве сорбционного сырья.

Бентонитовые глины на территории Воронежской области приурочены к сумской и киевской свитам палеогена [23]. На западе области в отложениях киевской свиты разведано Щербаковское месторождение. Полезная толща мощностью 0,5-12,0 м залегает на глубинах 4,2-26,6 м, подсчитанные запасы по категории $\mathrm{C}_{1}$ составляют 39536 тыс. м $^{3}$. По качеству глины характеризуются как высокодисперсные, высокопластичные.

Бентонитовые глины сумской свиты разрабатываются открытым способом на Никольском месторождении в Воробьевском районе. Запасы оценены по категориям $\mathrm{C}_{1}$ и $\mathrm{C}_{2}-821$ и 565 тыс. т. Они используются в качестве связующего компонента при изготовлении литейных форм, в производстве глинопорошков для буровых растворов и в качестве кормовой добавки. Продуктивная толща представлена светлосерыми с зеленоватым оттенком глинами, плотными, пластичными, с крупноблоковой отдельностью и полураковистым изломом. Она залегает на водораздельных пространствах, мощность ее изменяется от 3,5 до 5,5 м. Основным минералом глин является монтмориллонит. Содержание его во фракции менее 0,005 мм изменяется от 75 до $90 \%$. Постоянно присутствуют гидрослюда и каолинит (5-15\%), а среди неглинистых минералов - кварц, реже - клиноптилолит.

На территории Тамбовской области и востоке Воронежской бентониты приурочены к горелкинской свите миоцена. Их мощность до 20 м. Поисковыми работами выявлены участки с прогнозными ресурсами по $\mathrm{P}_{2}$, наиболее крупные из них - Зверяевский (347 млн т), Питимский (2871 млн т.) и Терновский (856 млн т.).

На западе Липецкой области бентонитовые глины приурочены к кремнисто-глинистым отложениям сантонского яруса верхнего мела [5]. Глины полиминеральные, с преобладанием монтмориллонита и примесью близких по сорбционным свойствам минераловсорбентов группы опала, очень редко - цеолитов. Основные запасы глин связаны с Воловским участком (65,2 млн т). Перспективы прироста запасов связаны с глинами усманской серии неогена на востоке и юговостоке области [8].

На территории Белгородской области киевские глины распространены в восточной и центральной её частях. Разрез свиты, как правило, трехчленный. В основании залегает маломощный $(0,2-1,0$ м) слой глауконит-кварцевого песка, с галькой. Средняя часть разреза представлена карбонатными, плотными, глинами (до 5 м), в нижней части алевритистыми и слюдистыми, с рассеянными зернами глауконита. Верхняя часть полностью сложена бентонитовыми некарбонатными высокопластичными глинами. Пласт достаточно хорошо выдержан по мощности (8-12 м) и минеральному составу.

Цеолитсодержащие породы с полезным компонентом выше 50 \% в Центрально-Черноземном реги- оне отсутствуют, как на всей территории ВосточноЕвропейской платформы. Альтернативой могут служить цеолитсодержащие породы с содержанием цеолитов менее $50 \%$, в среднем $20 \%$. К подобному сырью можно отнести силициты и их глинистые разности, в том числе и переходные бентонитовые разновидности. В ЦЧР известны проявления и месторождения, а также перспективные площади на сырье, пригодное для использования в качестве сорбентов. Цеолиты обнаружены в кремнисто-карбонатных породах Хотынецкого месторождения Орловской области в сантонских отложениях. Его запасы по изученным Образцовскому, Богородицкому, Воротынцевскому участкам составляют 56,5 млн $\mathrm{m}^{3}$. Объем добычи в 2010 году составил 34,7 тыс м².

Целенаправленные работы на поиски цеолитсодержащих отложений были проведены в Курской области, была выделена Восточная площадь в зоне распространения сантонских верхнемеловых пород. Дальнейшая детализация позволила выявить три участка (Халино-1, Халино-2, Жерновец) и подсчитать запасы цеолитсодержащего сырья по категориям $\mathrm{C}_{1}$ и $\mathrm{C}_{2}$. Продуктивный горизонт представлен кремнеземистыми мергелями мощностью 17,0-21,8 м с содержанием цеолита от 15,6 до 36,0 \%. В дальнейшем на Восточной площади выделены дополнительно три участка (Ново-Сергиевский, Есенки и Винниково), в Курском и Щигровском районах, где подсчитаны запасы цеолитсодержащих мергелей по категории $\mathrm{C}_{1}$ 3,9 млн т, $\mathrm{C}_{2}$ 13,0 млн т, Р 1 13,4 млн т. Перспективы дальнейшего прироста запасов цеолитсодержащих пород Восточной площади значительны. В зоне развития пород сантонского яруса также отмечаются перспективные участки и площади, расположенные на севере Курской у границы с Орловской областями.

\section{Агрохимическое сырьё}

Агроруды наряду с азотом являются основой для производства минеральных удобрений. На территории ЦЧР к агрорудам относятся фосфориты и глауконитсодержащие породы. Последние представляют калийное сырье. В настоящее время в сельском хозяйстве применяют в основном азотные удобрения, а применение фосфорных и калийных удобрений крайне мало. Внесение удобрений в почвы в развитых странах достигает нескольких десятков и даже сотен кг/га, что обеспечивает высокую урожайность зерновых и других культур.

Фосфориты желвакового типа на территории ЦЧР встречены в основании разрезов многих горизонтов и ярусов осадочного чехла [24]. Перспективные залежи фосфоритов связаны с мезокайнозойскими отложениями. В пределах региона имеется ряд месторождений желвакового типа, расположенных в Курской, Тамбовской и Воронежской областях. Наиболее известной является Щигровская группа, объединяющая 11 месторождений (рис. 5). Все они сеноманского возраста. Содержание Р2О5 в фосфоритах колеблется от 7 до $22 \%$, а суммарные запасы по категориям А, B, $\mathrm{C}_{1}$ 


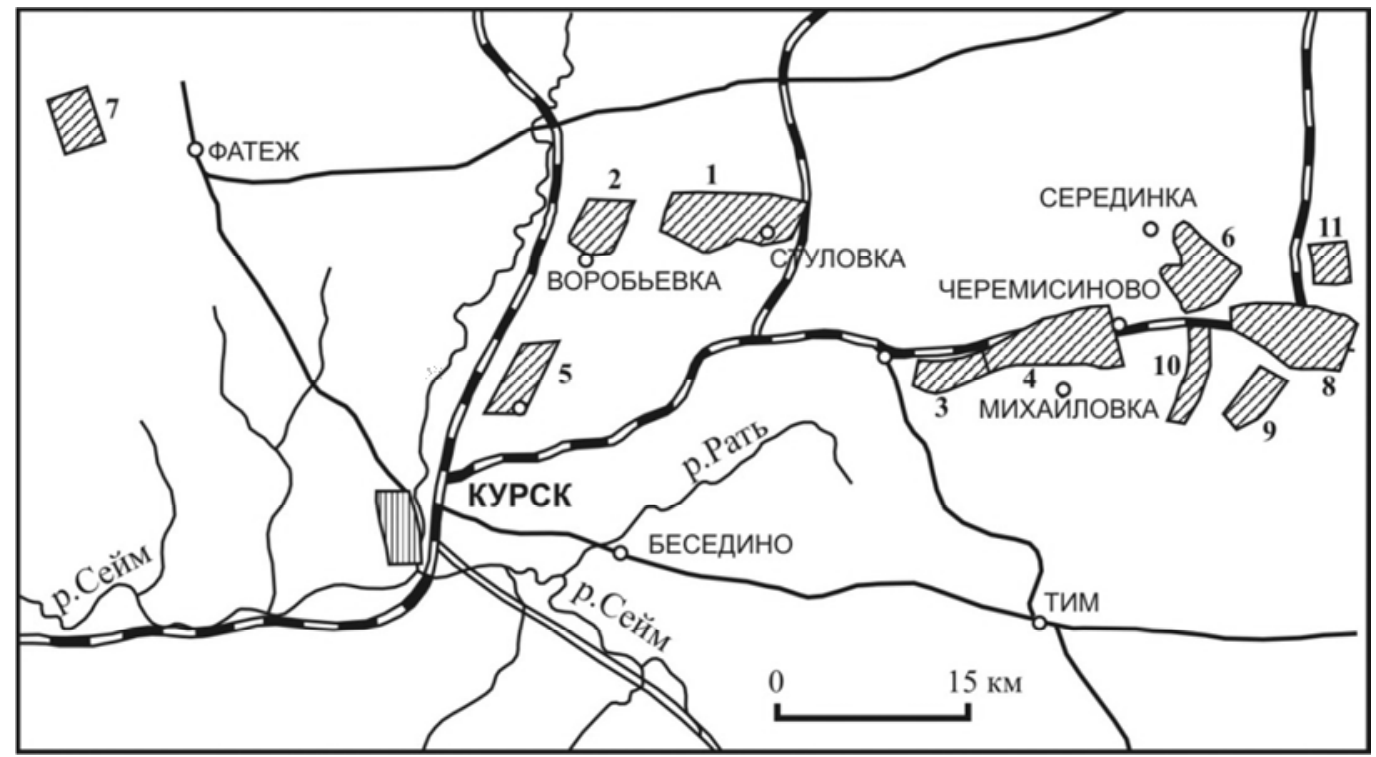

Puc. 5. Схема расположения Щигровской группы месторождений: 1 - Тускарское, 2 - Уколовское , 3 - Щигровское, 4 Трухачевское, 5 - Свободинское, 6 - Краснополянское, 7 - Ждановское, 8 - Мармыжское, 9 -Кошелевское, 10 - Покровское, 11 Сизеловское.

и $\mathrm{C}_{2}$ составляют более 140 млн т руды. Фосфатоносная полоса длиной около 100 и шириной в 25 км протягивается в широтном направлении, где и расположены все участки (месторождения), наиболее значительные из которых Трухачевский, Свободинский и Щигровский. В тектоническом отношении это наиболее приподнятая сводовая центральная часть Воронежской антеклизы, выделяемая как Щигровское поднятие.

На территории Тамбовской области разведано 18 месторождений [25], из которых Центральное наиболее крупное. Оно приурочено к отложениям верхнего альба и нижнего сеномана. Остальные мелкие. При разработке Центрального месторождения совместно с освоением титан-циркониевых россыпей должны извлекаться фосфориты из подстилающих альбских и глауконит из вмещающих сеноманских пород. Запасы фосфоритов в количестве 237,1 млн т отнесены к забалансовым. Вполне рентабельной может быть разработка и других мелких залежей небольшими коммерческими предприятиями. В Воронежской области разведано 16 участков крайне малых месторождений фосфоритов сеноманского яруса на северо-западе области и нижнего-среднего эоцена в южных районах, а также ряд проявлений пластовых фосфоритов в коре выветривания по мел-мергельным породам. Последние объединены в Хоперскую площадь.

Рассмотренные месторождения фосфоритов пригодны для производства фосфоритовой муки, использование которой наиболее эффективно в кислых почвах. Черноземы имеют щелочную реакцию, но в последнее время аммиачной водой, применяемой на свекловичных полях, закислены значительные посевные площади, что открывает возможности использования фосфоритной муки и в ЦЧР после предварительных агротехнических опытов на конкретных почвах.
Обзор месторождений фосфоритов показывает весьма значительные их запасы, однако, производство фосфатных удобрений в ЦЧР отсутствует. Основными проблемами фосфатной сырьевой базы в регионе, как и в Российской Федерации [25], является низкое качество и сложный минеральный состав руд большинства промышленных типов, что определяют их трудную обогатимость или необходимость применения многоступенчатых технологических схем.

Глаукониты могут использоваться для производства калийных удобрений, в химической промышленности, в качестве сорбентов и адсорбентов тяжелых металлов и радиоактивных элементов и для многих других целей. Положительное воздействие глауконита на развитие полезной микрофлоры почв, определяющих их плодородие, связанно с содержанием в глауконитах оксида калия. Площади пахотных земель, занятых под открытую разработку месторождений полезных ископаемых, после окончания добычи утрачивают свое плодородие на многие десятилетия. Покрытие рекультивированных участков слоем глауконит-кварцевого песка позволяет повысить урожайность многих культур на таких землях [26].

На территории ЦЧР развиты глауконитсодержащие породы (глауконита менее 35 \%). Они встречены в палеогеновых и меловых алевропесчаных породах. Проявления глауконитсодержащих отложений известны в двух районах Тамбовской области - Бондарском и Рассказовском, где глауконит приурочен к песчаным отложениям верхнеальбского подъяруса нижнего мела. Здесь выделены три перспективные площади с прогнозными ресурсами категории $\mathrm{P}_{1}$ 378,3 млн м². По предварительным работам запасы здесь оценены в объеме 10 млн м ${ }^{3}$. Средняя мощность продуктивной толщи - 9,6 м, вскрышных пород - от 5 до 11 м, среднее содержание глауконита - 31,2 \%, На 
Восточном участке месторождения Центральное в 2007 г, наряду с рудными минералами, ГКЗ учтены в качестве попутного компонента балансовые запасы глауконита в объеме 55,56 млн т по категории $\mathrm{C}_{2}$ с его содержанием в песках $11,4 \%$.

Выделено несколько перспективных площадей в пределах Белгородской, Курской и Воронежской областей, приуроченных к сеноманскому ярусу меловой системы и среднеэоценовым и нерасчлененным эоцен-олигоцененовым отложениям палеогена. Глаукониты сеноманского яруса приурочены к песчаноалевритистой толще (до 68 \%, в среднем 23,6-28,9 \%) [24]. Она имеет широкое распространение и близ поверхностное залегание, развита на северо-западе Воронежской, востоке Курской и юго-востоке Орловской областей.

Перспективные площади глауконитсодержащих отложений бучакской и харьковской свит палеогена выделяются на юге Воронежской области и югозападе Белгородской области. Глауконитсодержащие породы характеризуются тонкозернистостью, существенной примесью глинистого и слюдистого материала, отсутствием слоистости, хорошей выдержанностью гранулометрического и минерального составов в разрезах. Содержания полезного компонента, тяготеющего к фракции 0,1-0,25 мм, достигают 33 \% [27].

Благодаря широкому спектру использования глауконитов в различных отраслях промышленности и сельского хозяйства, можно сделать вывод о перспективах на поиски, разведку и его добычу. Потенциальность территории на этот вид полезного ископаемого весьма высокая, но возможность его использования в различных сферах экономики страны незначительна. Причиной такой ситуации служит, во-первых - экономическая несостоятельность предприятий, во вторых - вывод новой продукции на внутренний рынок всегда затруднителен [28].

\section{Формовочное сырьё}

На территории ЦЧР формовочное сырье представлено как кварцевыми песками, содержание которых в формовочных смесях достигает 85 - 95 \%, так и глинами различного состава. В пределах Липецкой области на Государственном балансе числится одно месторождение формовочных песков - Липецкое, с общими запасами промышленных категорий 1,3 млн т. Месторождение находится в ведении Ново-Липецкого металлургического комбината. По качеству формовочные пески соответствуют маркам Т 01А и Б, Т 016А и Б, П 01. На поиски новых месторождений перспективны аптские пески, широко развитые в области.

На территории Белгородской области, в Губкинском районе, во вскрыше Лебединского месторождения выявлены и утверждены запасы песков, пригодных после обогащения в качестве формовочных. В 2010 г было добыто 2365 тыс. т песков (30,6 \% общероссийской добычи), которые использованы для производства стройматериалов, ремонта бортов карьера и в природоохранных целях. Формовочные пески марки
T016А по категорий $\mathrm{A}+\mathrm{B}+\mathrm{C}_{1}$ составляют 132,1 млн т [29], что делает их конкурентоспособными с остальными месторождениями ЦЧР.

В Тамбовской области Госбалансом учтено два месторождения формовочных песков - Тамбовское и Полковое. Запасы песков первого составляют 3,9 млн т по категориям $\mathrm{A}+\mathrm{B}+\mathrm{C}_{1}$. Месторождение разрабатывает ОАО «Тамбовское карьероуправление» Российской компании «Формоматериалы» при проектной мощности предприятия 250 тыс. т в год. Формовочные пески применяются для получения литейных форм и стержней и являются составной частью формовочной шихты. Резервной базой ОАО «Тамбовское карьероуправление» является Полковое месторождение полужирных тонкозернистых формовочных песков. Месторождение находится в Госрезерве с запасами по категориям $\mathrm{A}+\mathrm{B}+\mathrm{C}_{1}-38,9$ млн т, $\mathrm{C}_{2}-230,0$ млн т. Качество песков отвечает требованиям ГОСТ 2138-91.

В Воронежской области учтены 8 месторождений формовочных материалов, из которых разведано 2 с суммарными запасами песков промышленных категорий 15,8 млн т и 5 - глин с запасами по категории $\mathrm{A}+\mathrm{B}+\mathrm{C}_{1} 38,9$ млн т и категории $\mathrm{C}_{2}-4,8$ млн т. Подгорненское месторождение с запасами 15,6 млн т песков расположено на северо-западной окраине г. Воронежа. Потребителями продукции являются предприятия г. Воронежа [30]. Станичное месторождение (Участок Южный) с запасами 133 тыс. т песков расположено в г. Борисоглебске и разрабатывается ОАО «БКМЗЛит». Потребителями продукции являются машиностроительные заводы России. Для выявления новых месторождений формовочных песков наиболее перспективна северная часть Воронежской области, прежде всего Рамонский и Новохоперский районы.

Суммарно запасы формовочных глин по состоянию на 01.01.2011 г учтены для участков Никольский, Майдан-Бентонитовый, Шевченковский, Подгорное2, Ново-Марковский и составляют 22,6 млн т [29]. В 2010 году добыча проводилась на Никольском 4,37 тыс. т, Майдан-Бентонитовом и Шевченковском участках с объемом 14,08 тыс.т. Глины используются в сельском хозяйстве. По своему прямому назначению практически не применяются.

Таким образом, ЦЧР с избытком обеспечена формовочным сырьём и даже является экспортером в другие регионы России.

\section{Химическое сырьё}

В качестве сырья для химической промышленности в пределах ЦЧР используются лишь мела Логовского месторождения Белгородской области (Шебекинский район). Запасы мела по категории $\mathrm{A}+\mathrm{B}+\mathrm{C}_{1}$ составляют 18,7 млн т. Мел используется, главным образом, в резиновом, лакокрасочном и полимерном производствах. Разрабатывает месторождение ЗАО «Шебекинский меловой завод» с объемами порядка 148 тыс. т в год. На сегодняшнее время данный завод является единственным поставщиком карбонатного сырья для химической промышленности в регионе 
при отсутствии иных конкурентоспособных производств. Перспективы прироста запасов мела неограничены, а наиболее чистые их разности приурочены к образованиям кампанского возраста [30].

\section{Стекольные пески}

На территории Центрально-Черноземного района в качестве стекольного сырья могут быть использованы пески аптского яруса нижнего мела (Богдановское месторождение), горелкинской свиты миоцена (Федоровского участка Сенцовского месторождения) и четвертичные отложения надпойменных террас (Секеринское месторождение) (см. рис. 3). Основными параметрами стекольных песков является высокая степень сортировки, с преобладанием фракций 0,8$0,1 \mathrm{Mм}$, низкие содержания красящих оксидов $\left(\mathrm{Fe}_{2} \mathrm{O}_{3}\right.$ и $\mathrm{TiO}_{2}$ ), а также глинозема $\mathrm{Al}_{2} \mathrm{O}_{3}$, сосредоточенного в глинистой примеси.

Всего на территории ЦЧР известно два месторождения стекольных песков, учтенных Государственным балансом запасов (ГКЗ): Секеринское в Курской области, Богдановское в Воронежской области (рис. 3). По состоянию на 01.01.2016 г. суммарные балансовые запасы стекольных песков по этим месторождениям составляют по категории $\mathrm{A}+\mathrm{B}-3365$ тыс. т (в том числе, 1504 тыс. т по необводненным, 1861 тыс. т - по обводненным), $\mathrm{A}+\mathrm{B}+\mathrm{C}_{1}-12555$ тыс. т (в том числе, 4726 тыс. т по необводненным, 6780 тыс. т - по обводненным) [31].

В Липецкой области территориальным балансом (ТКЗ) в нераспределенном фонде недр числятся запасы стекольных песков Федоровского участка Сенцовского месторождения - 254 тыс. т по категории $\mathrm{C}_{1}$ и 2374 тыс. т по категории $\mathrm{C}_{2}$.

Полезная толща Секеринского месторождения представлена аллювиальными песками второй надпойменной террасы р. Сейм. По химическому составу $51 \%$ проб кварцевых песков в природном виде соответствуют марке ПС-250, 49 \% марке Т. По результатам полупромышленных испытаний разработана схема обогащения, включающая классификацию, кавитационную обработку, обесшламливание, гравитационную и магнитную сепарацию, обеспечивающие получение из песков стекольного песка марок С-070 и ВС-050 по ГОСТ 22551-77.

Полезная толща Богдановского месторождения представлена мелкозернистыми кварцевыми песками криушанской свиты аптского яруса. Средневзвешенный состав песков полностью удовлетворяет требованиям ГОСТ 22551-77. Усредненная марка песков изменяется от Б-100-2 до Т. Полезная толща Федоровского участка Сениовского месторождения приурочена к отложениям горелкинской свиты миоцена. Государственным балансом запасов оно не учитывается, как не прошедшее Государственную экспертизу.

\section{Минеральные пигменты}

В ЦЧР минеральные краски представлены охрами желтоватого цвета, приуроченными к киевской свите палеогена, к полтавской серии палеоген-неогена и к четвертичным элювиально-делювиальным образованиям. Охры палеогена и неогена характеризуются хорошей укрывистостью, удовлетворительной маслоемкостью. Они имеют преимущественно ярко-желтый и золотистый цвет как в естественном виде, так и на олифе, и характеризуются марками А, Б, В, с преобладанием марки Б. Охры четвертичной системы высоким качеством не отличаются и могут быть использованы в качестве фасадных глинисто-известковых красок.

Наиболее известными учтенными государственным балансом являются три месторождения глинистых охр, расположенных в Воронежской области: Рудаевское, Журавское (Кантемировский район) и Бутурлиновское (Бутурлиновский район). Суммарные запасы охр утверждены по категориям $\mathrm{A}+\mathrm{B}+\mathrm{C}_{1}$ и составляют 2005,60 тыс. т, $\mathrm{C}_{2}-446,20$ тыс.т. Продуктивные толщи всех месторождений приурочены к отложениям палеогена и имеют ограниченное, часто линзовидное распространение, что делает практически невозможным дальнейшие перспективы прироста запасов. В настоящее время конкурентоспособность данных месторождений снижается из-за активного ввоза продукции в большом количестве из Китая, что сильно мешает реализации местной охры за пределы области.

Небольшие запасы охр имеются в Орловской и Тамбовской областях. Значительным резервом для получения минеральных пигментов могут служить как железные руды КМА, так и отходы горнорудного производства. Железные руды пригодны для получения сурика самых высоких марок, идущие в отвалы окисленные железистые кварциты также пригодны для получения сурика; некондиционные железные руды и выветрелые окраскованные сланцы - для получения охры, умбры и др. В Курской области данный вид сырья выявлен в пределах карьера Михайловского железорудного месторождения. Запасы их составляют 336,8 млн. т. Гематито-мартитовая рыхлая руда в естественном состоянии может применяться в качестве пигмента в клеевых и фасадных известковоцементных красках. Добыча их по назначению не производится.

\section{Выводы}

Анализ состояния минерально-сырьевой базы неметаллических полезных ископаемых ЦЧР показал, что в регионе имеются многие их виды, которые не только позволяют обеспечивать местные предприятия, но и экспортировать добываемую продукцию за его пределы. Вместе с тем по ряду потребляемого минерального сырья имеется дефицит (высококачественные фосфориты, песчано-гравийные смеси, прочный морозоустойчивый щебень, различные виды химического сырья за исключением карбонатного, стекольные пески). Для большинства неметаллов имеются перспективы наращивания запасов, особенно это касается вторичных каолинов, стекольных и фор- 
мовочных песков, которые можно получать из песчано-каолиновой мамонской толщи .

Высокая дифференциация осадочного процесса в платформенных условиях во многих случаях определяет комплексность многих месторождений неметаллического сырья. Так огнеупорные и тугоплавкие глины в разрезах могут чередоваться с кварцевыми песками, фосфориты с титан-циркониевыми россыпями и находиться в глауконитсодержащих псаммитах, мергели-натуралы в мелах и т.д.

Крупные железорудные месторождения во вскрыше содержат большие объёмы различных видов неметаллов - строительные и формовочные пески, мела, глины и суглинки как компоненты для производства цемента. Еще более ценные полезные ископаемые содержатся во вскрышных породах медно-никелевых месторождений (Нижнемамонского и Подколодновского) - вторичные каолины и кварцевые пески мамонской толщи, базальты для производства балластного щебня, мела, кирпично-черепичное сырьё. Эти полезные ископаемые в экономическом отношении могу заметно превышать экономический эффект от добычи медно-никелевых руд.

Разработка крупных месторождений, в первую очередь предприятий по добыче и переработки медноникелевых и титаноциркониевых руд, сопровождается появлением сопутствующих производств, коммуникаций, притоком рабочих сил и городообразованием. Это требует значительных ресурсов неметаллического сырья, что надо учитывать при прогнозировании развития производительных сил региона.

\section{ЛИТЕРАТУРА}

1. Государственный баланс запасов полезных ископаемых Российской Федерации на 1 январь 2011 г., Выпуск №75. Том 1.. Часть 21. Строительные камни: под ред. Е.В. Григорьев. - Москва 2010. - 83 с.

2. Савко, А. Д. Нерудные полезные ископаемые Черноземья / А. Д. Савко, Г. В. Холмовой, С. А. Ширшов / Тр. науч.исслед. ин-та геологии Воронеж. ун-та. - Вып.33. - Воронеж, 2005. -316 c.

3. Государственный баланс запасов полезных ископаемых Российской Федерации на 1 январь 2011 г. - Выпуск №74. Мел: под ред. Е.В. Григорьева. - Москва 2010. - 83 с.

4. Бурыкин, В. Н. Литология и полезные ископаемые юговостока Воронежской антеклизы / В. Н. Бурыкин, А. Д. Савко / Тр. науч.-исслед. ин-та геологии Воронеж. ун-та. Вып. 16. - Воронеж: 2003. $-100 \mathrm{c}$.

5. Дмитриев, Д. А. Сантонские отложения Правобережья среднего течения реки Дон / Д. А. Дмитриев, А. Д. Савко, А. В. Жабин // Тр. науч.-исслед. ин-та геологии Воронеж. унта. - Вып. 21. - Воронеж, 2004. - 104 с.

6. Литология и полезные ископаемые сантона центральной части КМА /А.Д. Савко [и др.] // Тр. науч.-исслед. ин-та геологии Воронеж. ун-та. - Вып. 55. - 2009. - 108 с.

7. Чигарев, А. Г. Кайнозойская кора выветривания Старооскольского района КМА/ А. Г. Чигарев, А. Д. Савко / Тр. науч.-исслед. ин-та геологии Воронеж. ун-та. - Вып. 63. 2011. $-101 \mathrm{c}$.

8. Холмовой, Г. В. Неогеновые и четвертичные отложения Срепднерусской возвышенности / Г. В. Холмовой, Б. В. Глушков. / Тр. науч.-исслед. ин-та геологии Воронеж. ун-та.
- Вып. 1. -20011. - 220 с.

9. Савко, А. Д. Минеральный состав огнеупорных глин Латненского типа / А. Д. Савко // Изв. АН СССР. - Сер. геол. 1977. - № 3. - С. 126-129.

10. Савко, А. Д. Огнеупорные глины и каолины Воронежской антеклизы / А. Д. Савко // Генезис и ресурсы каолинов и огнеупорных глин. - М.: Наука. - 1990. - С.35-47

11. Савко, А. Д. Минерагения аптских отложений Воронежской антеклизы. Статья 1. Огнеупорные глины и керамические глины / А. Д. Савко / Вест. Воронеж. гос. ун-та. - Сер. Геология. - 2011. - №1. - С. 116-136.

12. Савко, A. Д. Керамические глины ЦентральноЧерноземного района / А. Д. Савко, А. В. Крайнов // Тр. науч.-исслед. ин-та геологии Воронеж. ун-та. - Вып.88. Воронеж. $-2015 .-109$ с.

13. Крайнов, $A$. В. Минерально-сырьевая база тугоплавких и огнеупорных глин Центрально-Черноземного района и перспективы её развития / А. В. Крайнов, Д. А. Дмитриев // Вестник Воронеж. гос. ун-та. Сер. Геология. - 2017. - №4. C. $134-137$.

14. Андреенков, В. В. Естественные отделочные и облицовочные материалы из осадочных пород северо-востока Воронежской антеклизы / В. В. Андреенков, А. Д Савко // Тр. науч.-исслед. ин-та геологии Воронеж. ун-та. - Вып. 15. Воронеж, 2003. - 94 c.

15. Глины и условия их образования в неогене Воронежской антеклизы / Г. В. Холмовой [и др.] // Вестн. Воронеж. гос. ун-та. Сер. Геология. - Воронеж, 2014. - № 2. - С. 30-35.

16. Дубянский, А. А. Новые данные по геологии Курской и Воронежской областей / А.А. Дубянский // Тр. Воронеж. СХИ. - Воронеж. - 1940. - 146 с.

17. Савко, А. Д. Литология и полезные ископаемые мамонской песчано-каолиновой толщи / А. Д. Савко, С. В. Мануковский, Л. Т. Шевырев // Тр. науч.-исслед. ин-та геологии Воронеж. ун-та. - Вып.53. - Воронеж, 2008. - 112 с.

18. Вторичные каолины девона Воронежской антеклизы на примере месторождения Козинка / А. Д. Савко [и др.] // Вестник Воронеж. гос. ун-та. Сер. Геология. - 2018. - №2. C. 20-28.

19. Окороков, В. А. Литология фаменских отложений Воронежской антеклизы / В. А. Окороков, А. Д. Савко. - Воронеж : Воронежский гос. ун-т. - 1998. - 124 с.

20. Савко, А. Д. Природные сорбенты ЦЧЭР. Сообщ. 1 : Бентонитовые глины / А. Д. Савко, В. К. Бартенев, В. В. Горюшкин // Сорбционные и хроматографические процессы. - Воронеж, 2003. - Т. 3. - Вып. 6. - С. 745-757.

21. Природные сорбенты ЦЧЭР. Сообщение 2. Цеолитсодержащие породы/ А. Д. Савко [и др.] /. - Сорбционные и хроматографические процессы. - 2007. - Т. 7. - Вып. 3. - С. $508-519$.

22. Савко, А.Д. Природные сорбенты ЦЧЭР. Сообщение 3. Цеолиты в верхнемеловых отложениях Белгородской и Курской областей / А. Д. Савко, Е. О. Иванова, А. Г. Чигарев // Сорбционные и хроматографические процессы. 2010. - Т.10. - Вып.3. - С. 433-439.

23. Горюшкин, В. В. Бентонитовые глины юго-востока Центрально-Чернозем-ного района / В. В. Горюшкин, А. Д. Савко / Тр. науч.-исслед. ин-та геологии Воронеж. ун-та. Вып. 37. - 2006. - 176 с.

24. Савко, А. Д. Фосфориты Центрально-Черноземного района России / А. Д. Савко, В. И. Беляев, С. В. Мануковский. Воронеж : Изд-во Воронеж. гос. ун-та, 1994. - 183 с.

25. Минерально-сырьевая база фосфатного сырья России: состояние, проблемы и пути развития / Р. 3. Фахрутдинов [и др.] // Разведка и охрана недр. - 2005. - № 9. - С. 11-15. 
26. Дистанов, У. Г. Глаукониты. Природные сорбенты СССР / У.Г. Дистанов. - М., 1990. - С. 132-146.

27. Бартенев, В. К. Литология, фации и полезные ископаемые палеогена ЦЧЭР / В. К. Бартенев А. Д. Савко // Тр. науч.-исслед. ин-та геологии Воронеж. ун-та. - Вып.7. Воронеж, 2001. - $146 \mathrm{c}$.

28. Левченко, М. Л. Состояние сырьевой базы и возможности использования глауконитов в России / М. Л. Левченко // Минеральные ресурсы России. Экономика и управление. 2008. - №2. - С. 27-31

29. Государственный баланс запасов полезных ископаемых
РФ на 01 января 2011 г. - Выпуск №68. Формовочные материалы. - Часть 2, Центральный Федеральный Округ / под ред. Е.В. Григорьева. - Москва, 2011. - 75 с.

30. Иванова, E. О. Верхнемеловые отложения юго-запада ЦЧЭР (Белгородская и Курская области) / Е. О. Иванова, А. Д. Савко /. Тр. науч.-исслед. ин-та геологии Воронеж. ун-та. - Вып. 64. - 2011. - 95 с.

31. Крайнов, А. В. Минерально-сырьевая база стекольных песков Центрально-Черноземного района и перспективы её развития / А. В. Крайнов, Д. А. В. В. Горюшкин // Вестник Воронеж. гос. ун-та. Сер. Геология. - 2017. - №1 - С. 90-95.
Воронежский государственный университет

Савко Аркадий Дмитриевич, заведующий кафедрой исторической геологии и палеонтологии ВГУ, доктор геологоминералогических наук, профессор, Заслуженный геолог Poccuu

E-mail:savko@geol.vsu.ru

Тел.: +7(473) 220-86-34

Дмитриев Дмитрий Анатольевич, дочент кафедры исторической геологии и палеонтологии, кандидат геологоминералогических наук

E-mail:dmitgeol@yandex.ru

Тел.: 8 (473) 220-86-34

Крайнов Алексей Владимирович, научный сотрудник НИИ Геологии, кандидат геолого-минералогических наук E-mail: aleksey_vsu_geo@mail.ru

Тел.: 8-952-548-47-72

Милаш Алексей Васильевич, ведущий инженер НИИ Геологии, кандидат геолого-минералогических наук

E-mail:pirit86@yandex.ru

тел.: 8-903-030-51-47
Voronezh State University

Savko A. D., Head of the Historical Geology and Paleontology Department,

doctor of the Geological and Mineralogical Sciences,

Professor, Celebrated Geologist of Russia

E-mail:savko@geol.vsu.ru

Tel.: +7(473) 220-86-34

Dmitriev D. A., Associate professor of the Historical Geology and Paleontology Department, Candidate of Geological and

Mineralogical Sciences

E-mail:dmitgeol@yandex.ru

Tel.: 8 (473) 220-86-34

Krainov $A$. $V$., the master engineer of scientific research institute of Geology, Candidate of Geological and Mineralogical Sciences

E-mail: aleksey_vsu_geo@mail.ru; Tel.: 8-952-548-47-72

Milash A. V., the lead engineer of scientific research institute of Geology, Candidate of Geological and Mineralogical Sciences

E-mail: pirit86@yandex.ru

Tel.: 8-903-030-51-47 